
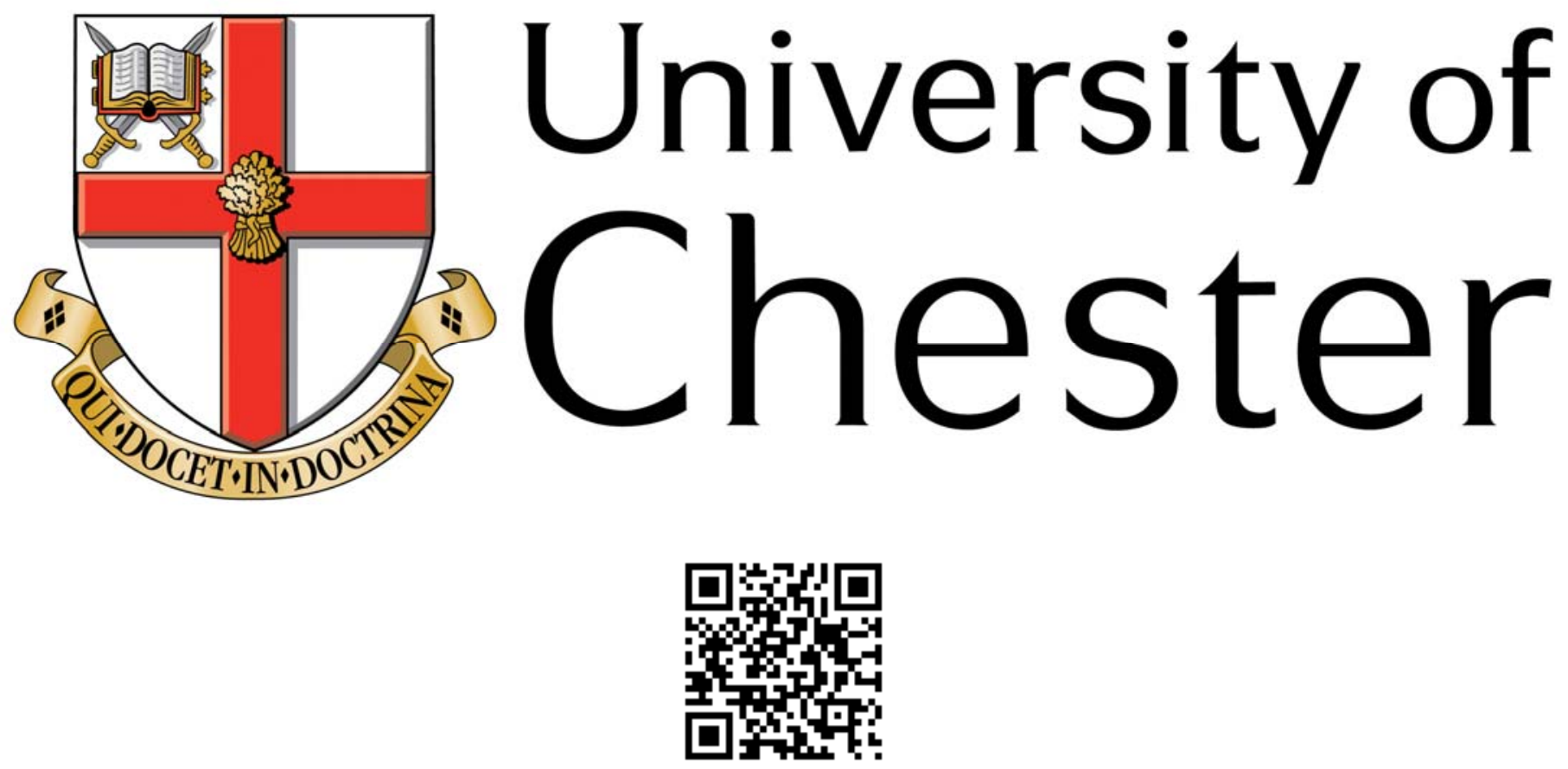

This work has been submitted to ChesterRep - the University of Chester's online research repository

\title{
http://chesterrep.openrepository.com
}

Author(s): Celia Deane-Drummond

Title: Gaia as science made myth: Implications for environmental ethics

Date: 1996

Originally published in: Studies in Christian Ethics

Example citation: Deane-Drummond, C. (1996). Gaia as science made myth: Implications for environmental ethics. Studies in Christian Ethics, 9(2), 1-15

Version of item: Author's post-print

Available at: http://hdl.handle.net/10034/15159 


\section{GAIA AS SCIENCE MADE MYTH: IMPLICATIONS FOR ENVIRONMENTAL ETHICS}

\section{Celia Deane-Drummond}

The ability of human 'subjects' to perceive the natural world around them as 'object' and 'other' than human is widely recognised as a necessary prerequisite for the birth of modern science.(1) Once the natural world is seen as purely materialistic, it can be understood through careful separation into its component parts. This so-called 'reductionist' approach is the springboard of modern scientific method. The separation of the material from the divine, humanity from 'nature', God from creation, the soul from the body all collectively contribute to 'dualistic' patterns of thought. It is hardly surprising, then, given the antidualistic stance of many modern writers of 'green' theology, that scientific thought is also believed to have contributed to the ecological crisis. Grace Jantzen, for example, considers that the 'metaphors of early modern science and its subsequent development have not been merely decorative, but have been models for the treatment both of women and of nature'.(2) Scientists can respond in a number of ways. One way is to insist that science is not as coldly objective as it appears. The early scientists were well aware of the supernatural, so that a spiritual horizon is compatible with modern science. All we need is a re-enchantment of science, though science itself remains intact. A more 'organic' approach is adopted instead of a 'mechanistic' one. For Griffin the individual purpose or telos of the individual parts becomes part of the revised science. This new science is still subject to criticism and so is 'enchanted', rather than 'sacred'.(3)

An alternative, more radical approach, is one which looks towards a 'holistic' scientific method which is directed towards understanding the whole system, rather than the separate parts. This has been a general characteristic of the field of ecology for a number of years. However, it took the maverick scientist James Lovelock to popularise this idea and extend it to include other branches of science as well. Now ecological principles are broadened so that the whole earth, not just a single community, is considered to act as a giant ecosystem known as the Gaia hypothesis. Many green theologians and philosophers have warmed to this hypothesis in a way which would have been impossible with more traditional scientific views. However, often Lovelock's ideas have been taken up in an uncritical way by writers unaware of both the scientific 
anomalies and ethical ambiguities.(4) It is the purpose of this paper to examine the different scientific interpretations of Gaia and show the implications of these for environmental ethics. It is hoped that a critical examination of the ambiguous ethical implications of Gaia will contribute to the discussion of the relationship between science and faith.

\section{Scientific Models of Gaia}

When James Lovelock first proposed his hypothesis, he presented Gaia as a single unified model. He recognised that, unlike other planets in our solar system, the earth is quite unique in its composition of gases which act like a blanket around the earth.(5) A unique feature of the earth is the presence of a sufficient concentration of oxygen to support life. Lovelock was able to predict that other planets would be inhospitable for life by analysis of their atmospheres. He also showed that the temperature of the earth and its gaseous composition has stayed constant over millions of years, whereas since the sun is getting progressively hotter, one would have predicted a rise in the earth's temperature and a change in its gaseous composition. No-one disputes these scientific facts. Lovelock proposed a novel explanation to account for the apparently anomalous features found on earth. He suggested that not only does life adapt to environmental conditions, but life itself serves to regulate those conditions to keep them within the necessary boundaries to support life. Inspired by the poet William Golding, he gave the name Gaia to his hypothesis, drawn from the idea of mother goddess of ancient mythology.(6)

The essential elegance of his hypothesis has attracted support from scientists and public alike. Moreover, as I hinted above, it offered a new way of approaching knowledge of the earth that looked at interactions on a whole planetary level - or geophysiology, to use Lovelock's nomenclature. Many scientists, however, were uneasy with Lovelock's ideas. One reason was that it seemed to suggest the idea of a purpose for life, namely to keep the environment constant. Such purpose or teleology is anathema to traditional science, which aims to provide purely rational explanations.(7)

Lovelock refuted the charge of purposefulness by showing that a computer model system called 'Daisyworld' could regulate the temperature of the earth automatically.(8) This model system shows changes in two populations of daisies, one of which is pale 
and reflects light and heat, while the other is dark and absorbs heat. The light daisies are presumed to have a higher temperature optimum for growth than the dark daisies. As the temperature rises, the numbers of light daisies increase, which leads to a drop in temperature as light is reflected from this variety. As the temperature falls, the dark daisies increase in number, which leads to a subsequent increase in surface temperature as more heat is absorbed. This computer model did not 'prove' his hypothesis, but showed that teleology need not be introduced into his model in order for it to work.

Other scientists were prepared to accept some, but not all of Lovelock's ideas.(9) It is this range of possible interpretations of Gaia that can lead to confusion in the debate, especially for non-specialists. Evidence which supports one aspect of Gaia can sometimes be used to support the hypothesis in toto.(10)

\section{(a) The Interconnected Model}

This interpretation of Gaia requires us to make the least number of assumptions and is accepted by the majority of scientists. It says, simply, that living organisms on the planet, collectively known as the biota, influence the external environment. This stops short of suggesting that the biota regulates environmental conditions. In some ways this interpretation of Gaia adds relatively little to scientific knowledge since it has been known for many years that living things alter their external conditions, such as in the production of carbon dioxide in respiration.(11) Nonetheless, this view does, at least, encourage a more holistic approach to science so that the way different living things influence the atmospheric composition can be examined and tested. . According to this understanding of Gaia it is quite possible that some species will act to shift atmospheric conditions away from equilibrium and so destabilise the system. If scientists just look for stabilising systems they may miss those which act in an opposite way and so distort the evidence in favour of 'regulation' by the biota.(12)

\section{(b) The Homeostatic Process Model}

This model of Gaia proposes that the biota regulates the atmospheric conditions of the planet, a view which Lovelock insists is essential for his hypothesis. According to this view different species act in concert so as to produce conditions necessary for life. More correctly this could be described as a rheostat, as it brings conditions back to pre-set norms. It is quite possible that the regulation system would become 'saturated' and then 
shift to a new state of equilibrium. This would presumably entail the death of all those species which required the earlier range of conditions. Such a catastrophic event has already taken place in the lifetime of the earth with the shift from, anaerobic to aerobic conditions in what would have appeared as a massive 'oxygen' pollution event.(13)

This rheostatic model sounds elegant, but it does beg a number of questions. For example, it is impossible to state which came first, the stable environmental conditions or life, adapted to such conditions. It is well known that inorganic systems have feedback mechanisms which keep conditions constant.(14) Biologists have sometimes used control systems theory taken from engineering as models to describe regulation in simple organisms.(15) It becomes far more difficult to envisage a control system with a sensor acting for all living organisms. While living things could, then, be seen as very much a contributory part of the rheostat system, there seems to be no obvious reason why life itself should persist per se in order for a rheostatic system to exist. In other words it is entirely possible that the new equilibrium state could be reached which effectively destroys all life, apart from possibly a few extremely resistant bacterial species.

The evidence in support of homeostatic regulation has focused around different known cycles of inorganic compounds, such as sulphur or nitrogen. The sulphur cycle is well documented and I will describe it briefly here by way of illustration. Marine algae are known to produce gaseous dimethyl sulphide, or DMS, which is then carried to the land through dissolution in rain droplets. Hence the production of DMS is part of the geophysiological recycling of sulphur from the sea to the land. That such recycling takes place is not particularly controversial scientifically. However, Lovelock suggested, in addition, that DMS produced by the algae is part of a Gaian system of climate regulation. As the temperature rises the DMS produced by the algae increases. The DMS acts as nucleation sites for cloud droplet formation, which affects the density of cloud above the ocean surface. A higher cloud density reduces the temperature and consequently the DMS flux. This allows an increase in temperature in the absence of cloud formation, which completes the cycle.(16) How far does the evidence suggest homeostatic regulation of temperature? Recent experiments show that the regulation of DMS production is very complex.(17) Furthermore, there is no evidence of a direct relationship between DMS production and climate changes.(18) These apparent inconsistencies in the data are important, since they point to a relationship between 
sulphur cycling and climate, but fall short of providing firm evidence for feedback regulation controlled by the biota. At best it seems to me that there is limited support for local Gaian systems acting in such a way so as to include biota in geophysiological processes such as the cycling of sulphur between the sea to the land.

\section{(c) The Cooperative Evolutionary Model}

This idea is one which draws on Lovelock's belief that Gaia is part of the evolutionary process of the earth. The language used to describe Gaia is that of a single organism, which has evolved so as to allow the persistence of life. The belief amongst scientists that the earth acts as a single organism is not new and was held by the Scottish scientist James Hutton in 1785 and the Russian scientist/philosopher Yergraf Korolenko who lived in the last century in the Ukraine.(19) An alternative to Lovelock's model is that inorganic material and life evolved together through a process described as coevolution.(20) Lovelock assumes that Gaia evolved independently of life, but emerged as a type of 'awakening' with the evolution of photosynthetic organisms, that is ones which could use carbon dioxide and sunlight as a form of energy.(21) The difficulty with all such speculations is that it is not possible to design a scientific test to prove these ideas.(22) It therefore clashes with one of the paradigms of science that requires an idea to be testable if it is to call itself science.(23)

The belief that the whole planet cooperates so as to act as a single organism seems to suggest a cooperative model for evolution rather than the competitive model characteristic of Darwin's theory. All species are acting in concert for the survival of the whole, rather than competing for individual survival. The concept that species evolved in such a way so as to encourage cooperation is especially popular amongst sociobiologists.(24) The cooperative behaviour which has evolved in species such as ants and other social animals becomes a model for human behaviour. This has clear ethical implications, which I will discuss below. The opposite alternative is that evolution has favoured the development of behaviour which is based on self-interest alone, the so called 'Selfish Gene' model of Richard Dawkins.(25) His model has attracted more hostility, perhaps, than the cooperative model of E.O. Wilson. Both seek to extend biology into the realm of ideology through evolutionary ideas. Lovelock's Gaia is more aligned to Wilson's position, though it has taken others to use his ideas as a basis for sociobiology.(26) 


\section{(d) The Ideological/Teleological Model}

The above cooperative evolutionary model slides into an ideological/ teleological model for Gaia where 'she' becomes part of a philosophical 'quest'.(27) While Lovelock has specifically denied that Gaia is teleological, some of the language he uses opens up the possibility of a teleological interpretation. He admits that over two thirds of those who wrote to him were concerned about the meaning of Gaia in the context of religious faith.(28) The way that Lovelock describes Gaia implies a consciousness, though that is not necessarily his intention. For example, in describing the ability of the earth to withstand violent interruptions from outer space he muses 'It is a tribute to the strength of Gaia that our planetary home was restored so promptly and effectively after these events'.(29) In his reflections on God and Gaia he remarks:

Belief in God is an act of faith and will remain so. In the same way it is otiose to try and prove that Gaia is alive. Instead, Gaia should be a way to view the Earth, ourselves and our relationships with living things.(30)

The directedness of Gaia is, then, towards the persistence of life, rather than any particular form of life, such as humans. The resonance of Gaia as science with the ancient religious understanding of the earth goddess has been taken up by the ecofeminist Anne Primavesi.(31)

Bound up with the concept of Gaia as ideology is the belief that human beings need to move away from understanding themselves as 'technologist toolmakers' reconstructing the earth, to one where they consider themselves as cooperating with the earth in a balanced relationship.(32) Pedler uses Gaia as a basis for the idea of a 'sustainable' future, that is one where human beings and their environment are in harmony and are part of the Gaian organism.(33)

\section{Ambiguous Ethical Implications}

Each of the above scientific interpretations of Gaia has ethical implications in terms of how far they serve to challenge or complement existing paradigms in environmental ethics.

(a) The Move Towards Collective Value

There is a wide spectrum of possible approaches to environmental ethics, from those 
who give priority to individuals, to those who consider collectives such as species, ecosystems and the biosphere have moral priority.(34) There is 'a strong movement in environmental ethics towards ethical consideration of collectives'.(35) The Gaia hypothesis reinforces this shift towards collective value and uses a similar language of 'community' and 'organism'. Gaia challenges the ethical stance which opts for more individualistic positions, such as that of Paul Taylor where all individual organisms have their own particular purpose or telos which gives them inherent worth.(36) According to Taylor's biocentric view all living beings have equal moral status, whereas according to Gaia higher status would be given to those organisms which exerted the greatest influence on the environment. The homeostatic, evolutionary and teleological aspects of Gaia reinforce a consequential approach to ethics of a type pioneered by Aldo Leopold.(37) I will return to a discussion of this again below. I am arguing here that the scientific version of Gaia which requires us to make the least number of assumptions (la above) has ethical implications, as it encourages consideration of collectives rather than individuals.

\section{(b) Resource Management Approaches}

An understanding of Gaia which includes homeostatic processes can, ironically perhaps, lead to two completely different ethical positions. The first stance is adopted by those concerned with the idea of the earth providing resources for human use. A second stance is adopted by those interested in the idea of giving value to processes and systems which I will cover in (c) below.

A resource management approach is not novel and is the most common attitude adopted by political organisations concerned with the environment. The focus is humancentred and action is judged according to the possible benefit or otherwise for human beings. John Passmore argues that humanity alone generates values and that there are no proper grounds on which we can find values in the non-human world.(38) His approach is unashamedly anthropocentric, in contrast with the biocentric approach which extends value to non-human creatures, as in Leopold.

It might seem anomalous that any Gaian view could be used to support an anthropocentric stance. The argument is as follows. The most extreme view, which barely deserves to be described as an 'ethic', is that since Gaian science shows that the earth will correct itself after change, human pollution is relatively incidental.(39) Not all 
conservationists welcome Gaian theory, as it seems to encourage a robust view of the earth which can withstand many more millennia of abuse by humans.(40) A more sophisticated view is that the human responsibility is to conserve those parts of the planet which act like the 'vital organs': that is the tropical rainforests, the deep sea algae and the prokaryotic bacteria.(41) Those species which are not essential to Gaian function would be dispensable. If Gaia was forced to a new equilibrium state this would lead to the destruction of many species, including humans. The survival of human beings, then, depends on avoiding any action which would force Gaia into a new equilibrium.(42)

Lovelock seems to object to any 'resource management' ideas, as if human beings could 'manage' the affairs of the earth when we have failed to manage our own human relationships.(43) He believes that ideas such as 'stewardship' still encourage a shortterm focus and one that is too anthropocentric. This fails to consider the overall health of the planet. He argues that we should consider ourselves as partners to the planet, acting as 'shopstewards' and 'representatives" of 'bacteria, fungi, slime moulds and fish, birds and animals'. In this he seems to be moving away from a purely anthropocentric stance, though the threat of human extinction is still part of his call for humans to live in partnership. If we fail to adopt this approach 'the rest of creation, will, as part of Gaia unconsciously move the earth itself to a new state, one where humans may no longer be welcome'.(44)

\section{(c) Links With Systemic Value}

Although Lovelock has not worked out his ethical position in any rigorous way, his focus on partnership and consideration of the overall process of Gaia bears some resemblance to the environmental ethics of Holmes Rolston III.(45) Holmes Rolston gives value to the ecosystem and biosphere as one which is 'life creating'. He describes systemic value in the following way:

This cardinal value, like the history, is not at all encapsulated in individuals, it too is smeared out into the system. The value in this system is not just the sum of the part values ... Systemic value is the productive process, its products are intrinsic values woven into instrumental relationships.(46)

He concludes, then, that 'The objective systemic process is an overriding value, not because it is indifferent to individuals, but because the process is both prior to and 
productive of individuality'.(47)

This would fit into a Gaian concept of a homeostatic process providing the means through which individual life is expressed. It seems to me that in giving attention to individual values Holmes Rolston avoids the danger implicit in other organismic ethical systems which can become forms of ecofascism - a point which I will return to under 2(e). However, in certain respect the biological basis of Rolston's ideas is naive. His views tend to reinforce the concepts of 'integrity' and 'stability' in ecosystems in a way that do not exist in practice. Brennan similarly notes that many conservationists write as if the ecological research of the last century did not exist.(48)

\section{(d) An Extension of the Land Ethic}

Aldo Leopold's work, A Sand County Almanac, written in 1949, was highly influential in the more recent shift towards collective value.(49) He argued that the land, that is soils, waters, plants and animals, all deserve moral consideration as part of the community of life. Baird Collicott, who draws on Leopold for his work, also gives value to collectives, but he believes that values are human generated (anthropogenic).(50) This contrasts with the more anthropocentric positions which I discussed in 2(b) above.

Callicott adopts a form of socio-biology where he considers that human beings have evolved in such a way that they treat non-humans as part of their community. The sociobiologist, Richard Alexander believes that if we neglect the genetic basis for ethical behaviour, then we are bound to fail to find ways forward:

those who have tried to analyse morality have failed to treat the human traits that underlie moral behaviour as outcomes of evolution - as outcomes of the process, dominated by natural selection, that forms the organising principle of modern biology.(51)

Callicott supports the Darwinian idea that natural selection favours altruistic behaviour, rather than selfish behaviour. For him this altruism extends to include the wider community of animals, plants and land. Objections similar to that levied against sociobiology in general include the problem of how we can distinguish between human behaviour that is generated by cultural factors and human behaviour that is genetically determined. More important, perhaps, socio-biological views encourage a form of biological determinism where human actions become determined by their genes.(52) 
This, is, ironically, the very opposite of the overall thrust of Gaian science, which is towards a more holistic, multidisciplinary approach. In this sense Callicott's views both cohere with and are in conjunction with the shift towards Gaia as ideology, which I will take up again below.

\section{(e) A Naturalistic Basis for Moral Value}

The tendency for a biological concept to become a basis for mythology is part of the history of the relationship between science and culture. For example, in the heyday of post-Darwinian science 'Evolutionism' was a powerful myth which seemed to offer a basis for a new philosophy which went beyond its role as a biological explanation for the origin of life.(53) It forms the foundation for subsequent socio-biological ideas, as well as those of Richard Dawkins. While E.O. Wilson would argue that Evolution has selected for altruistic behaviour, Dawkins suggests that Evolution has selected for selfish behaviour. Both authors assume that the behaviour puts the individual at a competitive advantage over other individuals. They are both relying on Darwinian notions of 'survival of the fittest'. In a sense both are forms of biological determinism which are Utopian and pessimistic respectively. Dawkins' stance becomes obvious in statements such as:

We are survival machines - robot vehicles blindly programmed to preserve the selfish molecules known as genes. This is a truth which still fills me with astonishment.(54)

Similar is an ethic which emerges from an understanding of Gaia as a foundation model for human behaviour. Sahtouris, for example, finds in Gaia clues for human behaviour.(55) She assumes that we are like immature adolescents who can only make progress by becoming more in tune with the inner workings of the planet. In this she echoes the eco-theology of Sallie McFague who regards sin as a failure to recognise our place in our planetary home.(56)

There are various possible objections to this idea. The first, most obvious one is that Gaia herself is not as benevolent as in Sahtouris' portrayal. Even Lovelock admits that Gaia keeps the world 'warm and comfortable for those who obey the rules, but is ruthless in her destruction of those who transgress'.(57) 
something which is, in this case Gaia, with something that is good or valuable.

Moreover, as I noted above, it is a strand of Gaia selected in a way which ignores the more ignoble qualities of the 'system'. The overall conclusion of Lovelock's Gaia is that those parts of the planet which are most valuable are the tropical forests, prokaryotic bacteria and algae, a point which I referred to above. Some follow the logic of this view in a more consistent way and suggest that human beings are 'parasites' and like a 'cancer' on the planet.(58)

Gaia as ideology shares many of the problems of the so-called 'deep ecology' of Arne Naess, Warwick Fox and others.(59) Pedler, for example, speaks of a new lifestyle that is 'Gaian' where the 'human race is an integral part of a single life force, sometimes called the earth organism, the earth spirit of Gaia', which in practice is an 'alternative to the ready made solutions offered by the industrial machine'.(60) It is a new consciousness that pervades every aspect of life, which is similar to deep ecology's focus as a 'consciousness movement', rather than an ethic per se.(61)

The new consciousness, that calls for a realisation and extension of the self into an all inclusive idea where there are no distinctions between self and non-self, is highly problematic. Identification with everything leads to a form of eco-fascism which bears some resemblance to Stoic patterns of thought.(62) Ironically, perhaps, an extension of the self tends to project self into the world in an 'anthropocentric' way, which is the opposite of the supposed holistic 'dream' of deep ecology. While the Gaia hypothesis does not, in itself, imply this form of mergence of self with the earth, those who have taken up the 'quest' for Gaia seem to share the same 'consciousness'.(63) It is as if the biological fact that we share the same molecules as nonliving matter gives us a rationale for a new metaphysics where all distinctions are ignored.

John Milbank argues that 'deep green' views are deceptive since they fail to acknowledge that concern for 'nature' in itself requires a separation between subject and object.(64) A new objectivity was sought in nature, even at the start of modernity. The 'turn to nature' is, then, part of the problem of modernity and so is unlikely to be the place where we find the 'key to value'.(65)

Gaia as ideology is also inconsistent with process philosophy. Two main criticisms are that Gaia is limited in its consideration of the earth rather than the whole universe and 
limited in its lack of consideration of the individual.(66) While both Gaia and process theology acknowledge 'processes' in the material world, Gaia takes a holistic stance that is lacking in process theology. Furthermore, the teleology that emerges in Gaian thought is very different from the teleology in process ideas, which are always directed towards individual maximum 'enrichment'. For Gaian thought the directness, if it exists, is more general and towards the maintenance of life.

In conclusion, at first sight the Gaia hypothesis could appear to present us with a model of life which supports one particular ethical stance or a form of ethical monism. However, the range of possible interpretations of Gaia from a scientific perspective mean that there is an equally wide range of ethical outcomes. This diversity leads to confusion in the debate since it is not always clear which particular version of Gaia is being used in support of a particular view. In particular, this highlights the problems of any attempt to find in the natural world a basis for ethics. A return to nature in Gaia is not likely to lead to clear ways forward and shares some of the problems of moral pluralism in general. There is an obvious danger of using Gaia as a way of supporting pre-determined ethical outcomes. However, there is little possibility that those who advocate a particular version of Gaia will be open enough to consider other possible ethical frameworks, such as that found in ethical systems based on the explicit recognition of ethical pluralism.(67) In this Gaia as a basis for ethics shares both the tendency for dogmatism in ethical monism and the tendency for relativism in ethical pluralism.

1 See, for example, G. Jantzen, 'Ethics and Energy' Studies in Christian Ethics (Volume 7 (1) 1994), pp. 17-31. D. Griffin argues against the idea that modern science requires a mechanistic view of nature, instead he suggests that belief in a transcendent God encouraged the 'disenchantment' of science, rather than science per se. See D.R. Griffin, ed. The Re-Enchantment of Science (New York: State University of New York Press 1988), pp. 1-46.

2 Jantzen 'Ethics and Energy', p. 21, op. cit. For other 'anti-dualistic' approaches see C. Birth, el al., eds. Liberating Life (Mary Knoll: Orbis 1990). For a critique of 'antidualism' see J. Milbank, 'Out of the Greenhouse' New Blackfriars (January 1993), pp. 4-14; B. Szerszynski, 'The Metaphysics of Environmental Concern - A Critique of Ecotheological Antidualism' Studies in Christian Ethics (Volume 6 (2) 1993), pp. 67-78.

3 Griffin bases his view on process philosophy, which I will discuss later in comparison with the Gaia hypothesis. Griffin, 'Introduction' The Re-Enchantment of Science, pp. 8-22, op. cit.

4 See C. Deanne-Drummond, 'God and Gaia: Myth or Reality?' Theology (July 1992), pp. 277-285. For a discussion of the use of Gaia by different environmentalists see A. Brannan Thinking About Nature (London: Routledge 1988). Stephen Clark seems to have retracted to some extent on his earlier use of Gaia, S. Clark How to Think About the Earth (London: Mowbray 1993), pp. 25-31.

$5 \quad$ Mars and Venus, for example, have atmospheres which contain over $90 \%$ carbon 
dioxide and less than 3\% nitrogen, while the earth has an atmosphere of $79 \%$ nitrogen, $21 \%$ oxygen and $0.03 \%$ carbon dioxide. For details of Lovelock's ideas see J. Lovelock Gaia (Oxford: Oxford University Press 1988); Gaia: The Practical Science of Planetary Medicine (London: Gaia Boods Ltd. 1991).

$6 \quad$ Lovelock The Ages of Gaia, p. 3, op. cit.

7 For a summary of W.F. Doolittle's and R. Dawkins' critiques of the Gaia hypothesis see C. Barlow, ed. From Gaia to Selfish Genes (Cambridge: Massachusetts Institute of Technology Press 1991), pp. 32-33.

8 Lovelock The Ages of Gaia, pp. 42-64, op. cit. It is quite possible to construct another computer model where biological organisms have a destabilising, rather than stabilising, effect on the climate.

$9 \quad$ For a range of scientific perspectives on Gaia see S.H. Schneider and P.J. Boston, eds. Scientists on Gaia (Cambridge: Massachusetts Institute of Technology Press 1991).

10 Stephen Clark seems surprised at the 'hasty scorn' of biologists. However, his suggestion that it 'conflicts with no known evolutionary principle' does not reflect the controversial claims of the evolutionary emergence of Gaia. Conventional geneticists find the notion of Gaia feeding back on hereditary material of the biota 'mythical' because it is untestable. See Clark, How to Think About the Earth, p. 29, op.cit; J.W. Kirchner, 'The Gaia Hypotheses: Are they Testable? Are they Useful?' in Schneider and Boston, eds. Scientists on Gaia, pp. 38-46, op. cit.

11 It is for this reason that the eminent biologist John Postgate insists that Gaia should remain a 'metaphor', not a mechanism. J. Postgate, 'Gaia Gets Too Big for Her Boots' New Scientist (Volume 118 1988), p. 60.

12 Kirchner argues that according to the Gaia hypothesis the biota had destabilising effects early in the history of the planet, but now they are supposed to be stabilising. This leads to a circular argument where 'I'm left wondering what conceivable events could not be used as evidence for Gaia. If Gaia stabilises and Gaia destabilises, then is there any possible behaviour that is not Gaian? Is Gaia, then, simply a theory so flexible (and by implication free of specific empirical content) that it can be wrapped around any paleoclimatic record?', in Schneider and Boston, eds. Scientists on Gaia, p. 41, op. cit.

13 Anaerobic is an environment that is free of oxygen, as opposed to aerobic conditions where oxygen is present. Lovelock estimates that the appearance of oxygen as the dominant atmospheric gas was between the Archean and Proterozoic periods. See Lovelock The Ages of Gaia, pp. 100-102, op. cit.

14 For a commentary on dissipative structures see J. Craik, 'The Gaia Hypothesis: Fact or Fancy?' Journal of the Marine Biological Association (Volume 69 1989), pp. 759768.

15 Control systems can operate in physical, chemical, biochemical and biological spheres. In other words the existence of a control system does not prove that 'life' is part of the regulation step. Ibid., pp. 759-768.

16 See RJ. Charlson, J.E. Lovelock, M.O. Andreae and S.G. Warren, 'Oceanic Phytoplankton, Atmospheric Sulphur, Cloud Albedo and Climate' Nature (Volume 326 1987), pp. 655-661.

17 There appear to be a number of different pools of dimethylsulphide which means that the factors which regulate production are highly complex. See M.O. Andreae, 'Geophysiological Interactions in the Global Sulphur Cycle', in Schneider and Boston, eds. Scientists on Gaia, pp. 131-138, op. cit.

18 Ibid., pp. 131-138. Andreae concludes that while there is evidence for release of DMS from different species of marine algae, there is no clear relationship between climate and speciation with respect to DMS production. Caldeira argues that the evolution of DMS as a means for climate control is not 'cost-effective' in evolutionary 
terms since the main cellular function is osmoregulation. (Osmoregulation is the biological terms used to describe the maintenance of cellular salt content in saline conditions). K. Caldeira, 'Evolutionary Pressures on Planktonic Dimethylsulphide Production', in Schneider and Boston, eds, Scientists on Gaia, pp. 153-158. op. cit. 19 Lovelock acknowledges his debt to J. Hutton, Y. Korolenko and his cousin, Vladimir Vernadsky. Lovelock Gaia, pp. 9-10, op. cit.

20 The idea of co-evolution separates the evolution of life from the response of the inorganic environment which cannot 'evolve' in the traditional Darwinian sense as it carried no genetic information. Lovelock's model implies that the biota regulates the inorganic environment as well, as part of one genetic complex.

21 Lovelock The Ages of Gaia, p. 78, op. cit.

22 Kirchner, in Schneider and Boston eds. Scientists on Gaia, pp. 38-46, op. cit.

23 Ibid., pp. 38-46.

24 One of the best known writers in this field is E.O. Wilson. For a review of his work see Barlow, 'From Ants to Anthropology: E.O. Wilson' in From Gaia to Selfish Genes, pp. 147-161, op. cit. Many biologists have rejected this use of biology as overstepping the boundary of the possible implications of genetics for human behaviour. See R.C. Lewontin, S. Rose and LJ. Kamin Not in Our Genes (Pantheon Books 1984); R.C. Lewontin The Doctrine of DNA (London: Penguin 1993).

25 R. Dawkins strongly rejects any 'organismic' ideas and argues that individual survival is the prime genetic determinant. See Barlow, 'Nature Red in Tooth and Claw' in From Gaia to Selfish Genes, pp. 195 ff., op. cit.

26 See especially K.J. Sharpe, 'Science and Religion: From Warfare over Sociobiology to a Working Alliance' Current Contents (No 25 June 24 1991), pp. 8-13; E. Garfield, 'Current Comments: The Science-Religion Connection' Current Contents (No 25 June 24 1991), pp. 5-8.

27 K. Pedler The Quest for Gaia (London: Harper Collins 1991). See also D. Abram, 'The Mechanical and the Organic: On the Impact of Metaphor in Science' in Schneider and Boston, eds. Scientists on Gaia, pp. 66-74, op. cit. I have commented elsewhere on the tendency of Gaia to become mythology. Deane-Drummond, 'God and Gaia: Myth or Reality?', op. cit

28 Lovelock The Ages of Gaia, p. 208.

29 Ibid., p. 86.

30 Ibid., p. 207.

31 A. Primavesi From Apocalypse to Genesis (London: Burns and Dates 1991), pp. $14 ; 34$.

32 Pedler rejects the idea of human beings acting as 'toolmakers', which presupposes the earth is a machine, in favour of human beings identifying with the planet as a living organism. Pedler The Quest for Gaia, pp. 13-21, op.cit.

33 Pedler claims that the blueprint for a sustainable future can only reappear if we look outside our own lives to Gaia and make that the primary, and not the secondary centre of our attention', ibid., p. 17. For a review of the idea of sustainability see C. Palmer, 'Some Problems with Sustainability' Studies in Christian Ethics (Volume 7 (1) 1994), pp. 52-62. Pedler's use of the term 'sustainability' was prior to it being taken over by those he would describe as 'technologist toolmakers'.

34 For a useful review of different approaches to environmental ethics see C. Palmer, 'A Bibliographical Essay on Environmental Ethics' Studies in Christian Ethics (Volume 7 (1) 1994), pp. 68-97.

35 Ibid., p. 84.

36 P. Taylor Respect for Nature: A Theory of Environmental Ethics (Princetown: Princetown University Press 1986).

37 A. Leopald A Sand Country Almanac (Oxford: Oxford University Press 1949). 
39 For examples of this view see, P. Bunyard and E. Goldsmith, eds. Gaia: The Thesis, the Mechanism and the Implications (Wadebridge Ecological Centre 1989).

40 Lovelock objects to the idea that Gaia 'gives industry the green light to pollute at will'. Rather, he insists that 'her unconscious goal is a planet fit for life' and if humans stand in the way 'we shall be eliminated with as little pity as would be shown by the micro-brain of an intercontinental ballistic nuclear missile in full flight to its target', Lovelock The Ages of Gaia, p. 212, op.cit.

41 Lovelock portrays the earth in 'organismic' terminology in Gaia: The Practical Science of Planetary Medicine, op.cit. See, in particular, 'The People Plague', pp. 153171.

42 A. Dobson Green Political Thought (London: Unwin Hyman 1990), p.45.

43 Lovelock draws a parallel between the idea of 'stewardship' and 'management' of artificial kidneys in a disabled body. By this he implies that any attempt to become stewards is misplaced because humans are setting themselves up as caretakers instead of being 'part of Gaia'. See J. Lovelock, 'Planetary Medicine: Stewards or Partners on Earth?' The Times Literary Supplement (September 131991), pp. 7-8; Lovelock Gaia: The Practical Science of Planetary Medicine, pp. 175ff., op.cit.

44 Lovelock, 'Planetary Medicine: Stewards or Partners on Earth?', p. 8, op.cit.

45 H. Rolston III Philosophy Gone Wild (New York: Prometheus 1989);

Environmental Ethics: Duties to and Values in the Natural World (Philadelphia: Temple University Press 1988)

46 Rolston III Environmental Ethics: Duties to and Values in the Natural World, p. 188, op.cit.

47 Ibid., p.191.

48 See A Brennan, 'Environmental Decision Making' in R.J. Berry, ed. Ethical Dilemmas (London: Chapman and Hall 1992), pp. 16-17.

49 Leopold A Sand County Almanac, op.cit.

50 B. Callicott In Defence of the Land Ethic (Albany: State University of New York 1989)

51 R. Alexander, cited in 'Introducing a New Science' in Barlow From Gaia to Selfish Genes, p. 176, op.cit.

52 See under n.24 above. R. Lewontin prefers the idea of a dialectical relationship between the biological and social spheres.

53 Both T.H. Huxley and his grandson Julian Huxley were keen supporters of Darwin's theory. J. Huxley attempted to integrate evolutionary views into his philosophy. See Barlow From Gain to Selfish Genes, pp. 67-84, op.cit. 
54 R. Dawkins, cited in Barlow From Gaia to Selfish Genes, p. 195, op.cit.

55 E. Sahtouris Gaia: The Human Journey from Chaos to Cosmos (New York: Simon and Schuster Inc. 1989) p. 19.

56 S. McFague The Body of God (London: SCM 1993), pp. 112-129.

57 Lovelock The Ages of Gaia, pp. 207-208, op.cit.

58 J. Ravetz 'Gaia and the Philosophy of Science' in Bunyard and Goldsmith, eds.

Gaia: The Thesis, the Mechanisms and the Implications, p. 135, op.cit. Lovelock implies this view particularly in 'The People Plague' Gaia: The Practical Science of Planetary Medicine, pp. 153-171, op. cit.

59 For an overview of deep ecology, especially the thought of A. Naess see Palmer 'A Bibliographical Essay on Environmental Ethics', pp. 90-92, op.cit. Michael Northcott notes the explicit acknowledgement of A. Naess' indebtedness to Gaia; M. Northcott, 'Is There a Green Christian Ethics?' Studies in Christian Ethics (Volume 7 (1) 1994), p.3

$60 \quad$ Pedler The Quest for Gaia, pp. 173-174, op.cit.

61 Warwick Fox argues that an altered change in consciousness is all that is required and as such makes 'ethics superfluous'. W. Fox Towards a Transpersonal Ecology (New York: Shambhala 1991), p.225.

62 See J. Cheney, 'The Neo-Stoicism of Radical Environmentalistm' Environmental Ethics (Volume 11 1989), pp. 293-326; Clark How to Think About the Earth, pp. 42-61, op.cit.

63 There are certain similarities in Pedler's understanding of the 'merged' self with the universe. However, he gives some detailed practical suggestions for Gaian living which are not usually forthcoming in deep ecology. Pedler, The Quest for Gaia, op.cit. 64 Milbank 'Out of the Greenhouse', p. 8, op.cit.; see also Clark How to Think About the Earth, pp. 31-41.

65 Milbank 'Out of the Greenhouse', p. 8, op.cit.

66 H.E. Daly and J.B. Cobb For the Common Good: Redirecting the Economy towards Community, the Environment and a Sustainable Future (London: Merlin Press 1990), pp. 381-383; Griffin The ReEnchantment of Science, p.21, op.cit.

67 For pluralist approaches to environmental ethics see, P. Wenz Environmental Justice (New York: State University of New York Press 1988); Brennan Thinking About Nature, op.cit.; C. Stone Earth and Outer Ethics (New York: Harper and Row 1987). 